\title{
O surgimento da navegação entre os povos dos sambaquis: argumentos, hipóteses e evidências
}

\author{
Flávio Rizzi Calippo*
}

\begin{abstract}
CALIPPO, F.R. O surgimento da navegação entre os povos dos sambaquis: argumentos, hipóteses e evidências. R. Museu Arq. Etn., São Paulo, n. 21, p. 31-49, 2011.
\end{abstract}

Resumo: As evidências arqueológicas encontradas ao longo do litoral brasileiro atestam que essa área era ocupada, desde, pelo menos, 8.000 anos $\mathrm{AP}$, por grupos pescadores coletores que exploravam os ambientes aquáticos costeiros. Embora a comunidade científica acredite que os sambaquieiros fossem exímios navegadores, evidências a esse respeito ainda são raras. Neste artigo, a partir de uma abordagem focada na Arqueologia Marítima, são apresentados argumentos, hipóteses e evidências que discutem o entendimento de que, além de uma forte relação econômica e simbólica com os ambientes aquáticos, os povos dos sambaquis se apropriaram de ou desenvolveram técnicas de navegação e artefatos náuticos.

Palavras-chave: Arqueologia Marítima - Sambaquis - Navegação pré-histórica.

\section{Introdução}

$\mathrm{P}$ or quase 8.000 anos os povos dos sambaquis distribuíram-se ao longo de uma extensa área litorânea, dominando grande parte das regiões costeiras e dos corpos d'água que atualmente compõem o litoral brasileiro. Para que tal ocupação possa ter acontecido os sambaquieiros devem ter acabo por desenvolver ou se apropriar de tecnologias náuticas. Embora o emprego de embarcações seja quase um consenso entre os pesquisadores brasileiros, são raras as referências a esse respeito na literatura arqueológica. Neste artigo, que foi, em parte, desenvolvido no âmbito da Tese Sociedade Sambaquieira, Comuni- dades Maritimas, ${ }^{1}$ procuramos apontar algumas evidências e hipóteses acerca da origem e do emprego dessas práticas entre os sambaquieiros e, consequentemente, dos modos através do quais eles teriam se apropriado culturalmente do mar e dos ambientes aquáticos.

De um modo geral, essas evidências relacionam-se a três conjuntos de dados, os quais dizem respeito, principalmente a: aspectos bioarqueológicos das populações sambaquieiras; a ocorrência de artefatos náuticos (em regiões da América do Sul, em períodos anteriores ou contemporâneos às idades atribuídas aos sam-

(1) Tese de Doutorado realizada no Museu de Arqueologia e Etnologia da Universidade de São Paulo (MAE/USP), sob a orientação de Maria Cristina Mineiro Scatamacchia, no âmbito do Programa Arqueológico do Baixo Vale do Ribeira, com bolsa do CNPq e financiamento da FAPESP. 
O surgimento da navegação entre os povos dos sambaquis: argumentos, hipóteses e evidências.

R. Museu Arq. Etn., São Paulo, n. 21, p. 31-49, 2011.

baquis); e evidências da utilização/fabricação de canoas presentes nos sambaquis. Um conjunto de dados que, mesmo indiretamente, pode atestar o desenvolvimento e a adoção de tecnologias náuticas e de conhecimentos relacionados às artes de navegação.

Nesse sentido, tais evidências são interpretadas a partir de uma Arqueologia Marítima que, como sugerido por Adams (2002), busca extrapolar os limites dos ambientes marinhos e analisa as diversas manifestações materiais de suas culturas a partir de suas interações com os diversos tipos de ambientes aquáticos.

Embora a compreensão de Adams (op. cit.) constitua-se como uma proposição ainda pouco explorada pela própria Arqueologia Marítima, ela é aqui adotada e desenvolvida pois suscita novas possibilidades para a construção de uma interpretação a respeito de um modo de vida cujas práticas sociais, culturais ou simbólicas possam estar associadas tanto ao mar quanto à terra.

Do ponto de vista teórico, tal proposta pode ser entendida como uma continuidade da Arqueologia Marítima criada por Keith Muckelroy que, no final dos anos de 1970, procurando superar a visão histórico-culturalista então predominante na Arqueologia praticada no mar, propôs que os arqueólogos começassem a estabelecer como principal objetivo o homem e não mais os artefatos (navios, cargas etc.) perdidos no mar. Muckelroy (1978) enfatizava que, nesse processo, também fosse levado em consideração tudo aquilo que está conectado com a vida no mar e não somente os restos dos navios e dos barcos que nele se encontram.

Com base na Arqueologia Marítima desenvolvida por Muckelroy, Adams (2002) sugere uma abordagem mais abrangente, a qual, ao mesmo tempo em que supera a compreensão da pesca e da faina do mar como uma sub-cultura distinta, permite que tanto as evidências marítimas como as terrestres sejam utilizadas para entender o universo marítimo e as relações que os povos estabeleciam com o mar (Calippo 2011).

Assim, a proposta de Adams se alinha com uma nova corrente da Arqueologia Marítima que, segundo Duran (2008: 92), busca o rompimento com as limitações geográficas do mundo submarino, com o foco específico nos sítios de naufrágios e a inclusão dos elementos terrestres associados, de uma maneira ou de outra, ao universo marítimo. Assim, os sítios abordados pela Arqueologia Marítima se encontrariam tanto em terra como no mar, e, mais do que o ambiente onde ocorrem (ou da maneira que devemos utilizar para acessá-los), o que mais importa são as compreensões dos processos e as correlações com o universo marítimo que estão preservadas em seu interior (Fontenoy 1998).

Sob esse ponto de vista, os desdobramentos de uma cultura marítima não terminariam exatamente no último resquício de água salgada que banha a praia ou a linha de costa de diferentes ilhas e continentes. Ela estenderia sua influência terra adentro, englobando também equipamentos, estruturas produtivas, religiosas e mesmo cidades inteiras (Duran 2008: 92).

[...] those 'related objects on the shore' and 'coastal communities' explicitly ruled out by Keith Muckelroy would just as explicitly be ruled in today. Indeed, it is through them that coastal and sea-born maritime concerns articulate with society at large. Today, then, maritime archaeology is the study of material (Adams 2002: 328).

Desse modo, devem compor o universo marítimo dos povos dos sambaquis não só os ambientes oceânicos e marinhos, mas, também, todos aqueles ambientes aquáticos associados à região costeira, sendo concernidos como intrínsecos ao universo marítimo todos os ambientes percebidos e culturalmente apropriados pelos povos dos sambaquis, independentemente de quão próximos ao mar eles se encontrem (Calippo 2011).

Embora aqui se acredite que os sambaquieiros pudessem constituir suas próprias concepções a respeito desses diferentes compartimentos "molhados" e, também, das diversas regiões emersas, é importante ressaltar que a atual subdivisão dessas áreas (em marinhos, oceânicos, lacustres, estuarinos etc.) e os "preconceitos" interpretativos que se criam em relação a elas, são, de certo modo, influenciados pela maneira como nós, arqueólogos, compreendemos os ambientes aquáticos. 
Segundo Blot (1999), Read (1996) e Rambelli (2003), em sua maioria, essas compreensões devem ser reflexo da influência de como nossa sociedade concebe culturalmente o mar. Concepção essa que não se restringe somente às questões brasileiras, pois a separação entre marítimos e continentais perpetua-se devido ao fato de que "nas sociedades ocidentais, o mar permanece ainda entendido como um espaço mal conhecido, perigoso, fora da cultura terrestre, fora da lei que impera no continente" (Diegues 1998: 58). Nesse processo, pode-se identificar uma espécie de "resistência" em se voltar olhares para o mar, pois "a região submarina se torna, dessa forma, símbolo do inconsciente" (Diegues 2000: 159; Rambelli 2003: 12).

Como neste artigo buscamos identificar e discutir diversos tipos de dados arqueológicos como evidências do emprego de artefatos náuticos pelos povos dos sambaquis, não podemos, a partir dessa perspectiva da Arqueologia Marítima, deixar de considerar também a correlação das embarcações e da navegação com as práticas sociais (econômicas e simbólicas) desenvolvidas pelos sambaquieiros. Para Malinowski, por exemplo, a canoa não era somente um artefato ou um veículo através do qual os nativos locomoviam-se entre as ilhas. "Ela está envolvida em uma atmosfera de romance, constituída de tradições e experiências pessoais" (Malinowski 1984: 87).

\section{É um objeto de culto e admiração, uma} coisa viva que possui personalidade própria. Para o nativo, a canoa representa o instrumento poderoso que lhe permite tornar-se senhor da natureza, capaz de singrar mares perigosos em demanda a terras distantes. Está associada a viagens [...] que ele expressa em cantigas e estórias (Malinowski, idem: 87).

Segundo esse autor, por mais que houvesse uma organização social subjacente à construção das embarcações, ela não se constitui somente de indivíduos (líder, especialistas e trabalhadores) cuja função é construir as canoas, navegá-las e dar apoio ao kula. $\mathrm{O}$ especialista (que pode ser mais de um), da mesma forma que tem os conhecimentos para construir a canoa e fazer os entalhes, é responsável também por executar a magia. Para os trobriandeses, além da constru- ção das canoas, é a magia que propicia a navegação, o salvamento, o kula, as trocas, a pesca e a coleta dos recursos mais importantes (Malinowski, ibidem: 94). Nesse sentido a canoa não é somente um artefato usado para a navegação, ela "representa o poderoso instrumento que lhes permite tornarem-se senhores da natureza, capaz de singrar mares perigosos em demanda a terras distantes" (Malinowski, ibidem: 88).

\section{As evidências bioarqueológicas}

O primeiro desses conjuntos diz respeito a dados provenientes de estudos bioarqueológicos, os quais, com base na análise de anomalias ósseas presentes em indivíduos sambaquieiros, sugerem o estabelecimento de atividades náuticas ligadas à prática de mergulhos e à utilização de embarcações a remo. Especificamente em relação às anomalias, essas podem ser de três tipos: exostoses auriculares (anomalias ósseas que se formam na base do canal auditivo externo), modificações nas estruturas de inserção dos feixes musculares e desgastes ósseos irregulares.

Segundo Okumura et al. (2005/2006) e Schell-Ybert et al. (2003), as exostoses auriculares estão relacionadas, principalmente, a constantes imersões em águas frias e salgadas ou exposição ao vento. $\mathrm{O}$ que indicaria certa adaptabilidade e domínio de técnicas associadas ao mergulho livre por parte dos sambaquieiros. Ao analisar as exostoses do sambaqui Jabuticabeira II (em Santa Catarina), Okumura indica que tais anomalias seriam mais comuns em indivíduos do sexo masculino:

"This type of exostoses is reported to be caused by frequent dives in cool (Chaplin \& Stewart 1998; Kennedy 1986) or salt water (Peixoto 1989)" Okumura (2005/2006: 275).

No que tange à modificação das estruturas de inserção dos feixes musculares e dos desgastes ósseos irregulares, Carvalho (2004) aponta uma associação dessas anomalias à prática de atividades ligadas à natação, à utilização de remos (em pé e sentandó) e, indiretamente, à fabricação de canoas. 
Com base na análise das articulações de sambaquis de Santa Catarina e do Rio de Janeiro, Carvalho (2004: 152) aponta que os conjuntos articulares mais afetados são, respectivamente, pulso e cotovelo. Entre as populações pré-históricas, segundo a autora, "o grande acometimento do pulso deve estar ligado, principalmente, a movimentos que envolvam ao mesmo tempo, firmeza e mobilidade da região, [...], como ocorre, por exemplo, na confecção de artefatos (polimento, raspagem), em atividades envolvendo redução de matéria-prima ou [na preparação] de alimentos (raspagem, moagem)" (Carvalho, op. cit: 152). Atividades também realizadas ao longo do processo de fabricação de canoas e embarcações.

No caso do estresse articular do cotovelo, o mais provável é que estaria associado "[...] ao transporte de peso ou à flexão/ extensão do antebraço contra algum tipo de resistência, como pode ocorrer na remada e no arrastar redes, por exemplo" (Carvalho, ibidem: 152).

A seguir ao pulso e ao cotovelo, segundo a autora, a articulação que apresenta maior desgaste é a do ombro. Embora em segundo plano, entende-se, com base no resultado dessas análises, que tais alterações articulares indicam também certa relação com a prática de atividades náuticas (arremesso de arpões e lanças), a fabricação de canoas (machados e enxós²) e aquelas relacionadas aos ambientes aquáticos (natação), pois:

O ombro é particularmente sensível a atividades que envolvam movimentos de grande extensão acima da cabeça como o arremesso de objetos, a natação moderna e a aplicação de diferentes golpes acompanhados de ferramentas diversas (como machados, marretas, porretes etc.) e associados a movimentos amplos (Carvalho 2004: 155 apud Whiting e Zernicke 2001).

(2) Ferramentas normalmente utilizadas para a escavação do interior de canoas monóxilas (ver figura 6.22).
O tornozelo "foi uma das articulações menos afetadas nas séries estudadas e, como possui [...] um papel imprescindivel na marcha e no suporte do peso corporal" (Carvalho 2004: 156), a autora sugere que possa ter havido um menor esforço decorrente de atividades de caminhada em relação à utilização de embarcações.

No que tange aos marcadores de estresse muscular, Carvalho aponta a manutenção do mesmo padrão, que, de uma maneira geral, está relacionado a uma maior utilização dos membros superiores em relação aos inferiores. Nos membros superiores, "[...] movimentos envolvendo o conjunto braço/ombro devem ter sido freqüentes em todas as séries, enfatizados pelo desenvolvimento da inserção do deltóide e peitoral maior" (Carvalho2004: 162). Segundo a autora, o desenvolvimento das áreas correspondentes de fixação muscular está associado a diversas atividades como "[...] a utilização de remos duplos, a retirada de peles animais, o manuseio de ferramentas como machados [para a fabricação de canoas], enxadas, picaretas, a utilização de grandes pilões, a natação (especialmente nos movimentos da natação moderna), no lançamento de objetos, entre outros" (Carvalho, ibidem: 156).

Outro músculo bastante solicitado foi o bíceps, o qual também está relacionado à utilização de remos. Segundo Carvalho, Capasso et al. (1999) e Hawkey e Merbs (1995) apontam que o desenvolvimento "[...] bilateral desse músculo é freqüentemente relacionado ao carregamento de pesos com o braço flexionado e a utilização de remos duplos" (Carvalho 2004: 162). A atividade - remada - também é indicada em consequência dos índices de robusticidade obtidos nos sambaquieiros em relação ao músculo pronador quadrado. A autora relaciona, ainda, a utilização desses músculos em atividades ligadas ao "[...] processamento de alimentos pela moagem ou raspagem, ao polimento de diferentes artefatos [como as lâminas de machado] e a outros movimentos que podem ser realizados com o cotovelo flexionado e o antebraço em pronação" (Carvalho, op. cit.: 162). 
No caso do tríceps, "[...] mais uma vez o manejo de remos pode ser uma explicação, ${ }^{3}$ juntamente com a utilização de [...] machados, [...] lanças longas ou arpões, acompanhados de um arremesso rápido e a pouca distância do alvo, o que poderia ser associado a pesca em águas calmas e com boa visibilidade" (Carvalho, ibidem: 163). A autora chama a atenção, ainda, para:

[...] o uso de embarcações que se utilizassem de longas hastes como propulsores [para jangadas e canoas] e remos, tipo de transporte comum em águas calmas e com poucas correntes, onde o condutor geralmente se posiciona de pé e o esforço é compartilhado entre ambos os braços. Não se deve descartar, porém, o emprego de machados (Carvalho, ibidem: 163).

Ao concluir sua análise, a autora indica ainda que "o esforço dedicado à utilização de arpões, propulsores, arcos, lanças e etc., não sobrepujou o esforço dedicado a atividades como o uso de embarcações e redes de pesca" (Carvalho, ibidem: 170). Sugerindo que, embora todas as comunidades sambaquieiras tenham mantido contato com os ambientes aquáticos, tal relação não tenha se dado apenas a partir de suas margens. É provável que, efetivamente, os sambaquieiros tenham rompido o limite terra-mar, aventurando-se em meio às águas lagunares e costeiras.

\section{As primeiras evidências de navegação na América do Sul}

Embora Carvalho (2004) tenha sugerido a utilização de diferentes tipos de embarcações (canoas e balsas) e propulsores (remos, remos duplos, varas e hastes), existem outros tipos de artefatos náuticos, alguns tecnologicamente mais simples, que podem indicar não só a ado-

(3) A extensão do antebraço contra resistência pode ocorrer, por exemplo, em contraposição à flexão do braço oposto na remada e na manutenção do equilíbrio e mudanças de orientação da embarcação, que estariam em concordância com a navegação em águas agitadas e com correntes fortes (Carvalho 2004: 163). ção de uma tecnologia náutica, mas, também, o seu desenvolvimento pelos povos sambaquieiros.

Tal perspectiva é difícil de ser considerada quando tratamos de embarcações mais complexas, as quais são formadas a partir da articulação de diversas inovações tecnológicas que as transformam em artefatos, cuja construção e utilização requerem o trabalho de especialistas. Entretanto, quando nos referimos a peças náuticas mais simples, talvez, a possibilidade do desenvolvimento da navegação possa ser comparada ao desenvolvimento de qualquer outro tipo de tecnologia pré-histórica.

Quando pensamos em uma embarcação pré-histórica brasileira a imagem mais comum é a de uma canoa. No entanto, existem diversos outros tipos de artefatos flutuadores que poderiam ser empregados na pesca e no cotidiano dos sambaquieiros que não requerem, necessariamente, o mesmo grau de domínio tecnológico empregado nas canoas. Alguns, inclusive, nem poderiam ser considerados embarcações.

Embora não haja uma divisão precisa entre eles, Hornell (1970) sugere uma subdivisão dos flutuadores em duas categorias: flutuadores de natação (swimming floats) e flutuadores propulsionados (riding floats).

Os flutuadores de natação são acessórios mais simples, como pequenos pedaços de madeira, toras, bolsas de pele etc., utilizados para auxiliar a flutuação do corpo enquanto o individuo permanece parado, ou segue ao sabor da correnteza ou desloca-se com uma propulsão e direção gerada por suas penas e braços (Fig. 1). Uma árvore seguindo corrente abaixo, segundo Hornell (1970: 1), foi o primeiro estímulo para a inventividade do homem nessa direção.

Nos flutuadores propulsionados, por outro lado, em vez de ficarem imersos os indivíduos (e apenas um) permanecem sobre uma tora ou feixe de junco e, além dos membros, utilizam como propulsores varas, hastes, remos etc..

Existem diversos exemplos da utilização de flutuadores por populações pescadoras tradicionais, indígenas e aborígenes ao longo de todo o mundo. Na Austrália, por exemplo, segundo Stokes (1846: 11, 15-16), existem inúmeros exemplos aborígenes da utilização de toras como flutuadores de natação. Eles são frequentemen- 


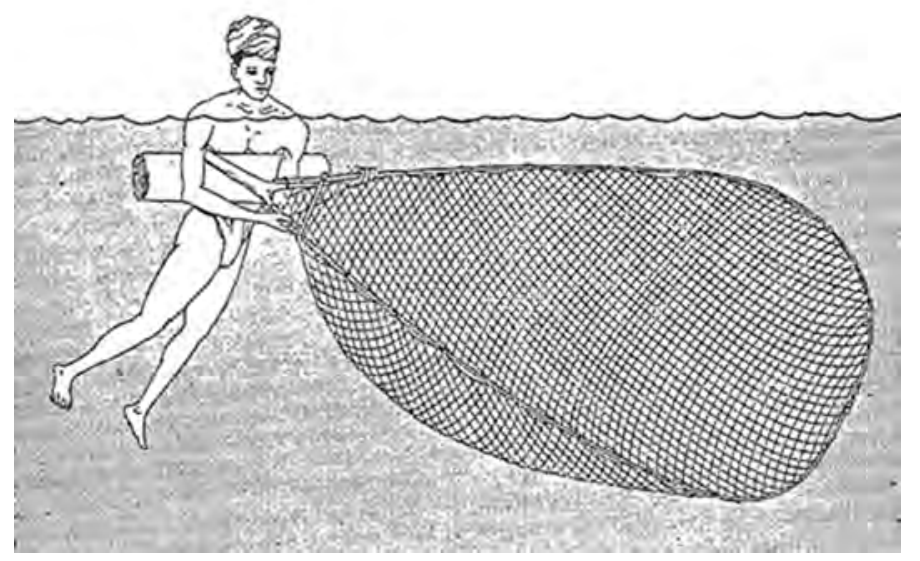

Fig. 1. Representação de um pescador do Rio Kaveri (sul da Índia) usando um flutuador de (Hornell 1970: 2).

te encontrados ao longo da costa norte australiana, onde os aborígenes utilizam uma pequena tora ou um pedaço de madeira, preso ao peito, para fazer longas jornadas entre as ilhas e o continente. Na América, Mason (1895: 334) indica o uso de um flutuador de madeira como uma prática de tribos do Golfo da Califórnia para descansar seus braços quando nadam.

Hornell (1970) afirma que uma definição mínima sobre flutuadores não pode ser apresentada sem uma referência sobre as pranchas havaianas. Embora elas sejam hoje utilizadas para a prática de esporte, Lisiansky (1814), que visitou a ilha em 1804 , não viu canoas lá, mas muitos nativos vieram ao barco utilizando, cada um, uma prancha de madeira.

Do ponto de vista tecnológico, não seria impossível que os sambaquieiros tivessem desenvolvido e utilizado flutuadores e, a partir dessa experimentação náutica (realizada, principalmente, nos primeiros momentos da ocupação sambaquieira, onde estariam se adaptando aos ambientes costeiros), desenvolvido inovações que levaram à construção de balsas e à transformação de flutuadores em canoas. Além de possuírem conhecimentos suficientes para a sua construção, os padrões de desgaste articular e de estresse muscular, indicados por Carvalho (2004), descritos no item anterior, também condizem com a utilização de ambos os tipos de flutuadores, de elementos de propulsão e da construção de canoas.
Embora ainda não existam muitas evidências materiais que nos permitam discutir o desenvolvimento de uma tecnologia náutica sambaquieira, em função desses argumentos, não podemos negá-la. Nesse sentido, defendemos que tanto a navegação como a construção de flutuadores, balsas e canoas poderiam ter sido desenvolvidas pelos povos dos sambaquis, assim como também foram desenvolvidas por outros povos ao longo do atual território brasileiro, sul americano e do mundo todo.

Uma vez estabelecida, entre os sambaquieiros, as tecnologias necessárias para a preparação dos flutuadores, o próximo passo no sentido do desenvolvimento tecnológico das embarcações deveria estar associado à transformação desses em balsas, jangadas e canoas monólixas. Hornell (1970: 1) aponta que para o surgimento de balsas ou jangadas, bastaria apenas que as toras ou feixes de juncos fossem amarrados juntos, lado a lado.

No que tange a artefatos náuticos mais complexos, elaborados a partir de técnicas que suplantam a escavação, modelagem e agregação de flutuadores (como ocorre, por exemplo, na construção de barcos, em que diferentes tipos de estruturas são unidos para formar um casco), o mais provável é que tal desenvolvimento tecnológico não tenha sido atingido pelos sambaquieiros. Além de não ser encontrado um ferramental que permitisse a construção desses tipos de embarcações, tais barcos não são encontrados mesmo entre as sociedades que, posteriormente, vieram a habitar as áreas antes ocupadas pelos sambaquieiros.

Voltando à questão dos artefatos náuticos mais simples, Carabias (2000) destaca uma série de evidências pré-hispânicas de navegação ao longo da costa norte do Chile. O mais antigo vestígio material dessa navegação diz respeito a uma miniatura de balsa de totora (junco) encontrada em um "[...] cementerio de túmulos, ubicado $6 \mathrm{~km}$ al sur de la desembocadura del rio Loa, fechada em 215 d.C." (Fig. 2) (Llagostera 1990, apud Carabias 2000: 34). 


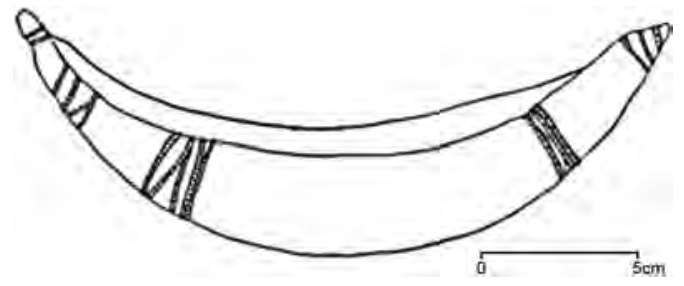

Fig. 2. Miniatura de balsa de junco encontrada, no norte do Chile (Carabias 2000: 34).

No entanto, é no interior do Brasil que pode existir a mais antiga evidência de fabrico e construção de canoas, a qual colabora para refutar as compreensões que entendem que a tecnologia náutica só poderia ter chegado à América do Sul após ser desenvolvida por povos tecnologicamente e culturalmente mais avançados. Na realidade, mesmo que a navegação não tenha surgido de maneira independente, o mais provável é que em cada comunidade ou aldeia, onde novos grupos começavam a utilizar tal tecnologia, ela fosse constantemente modificada a partir das inovações e das percepções desenvolvidas com base na experimentação dos indivíduos e dos grupos a que pertenciam.
En um comienzo, el tema de ela navegación en América sirvió para alimentar inconsistentes hipótesis difusionistas de poblamiento; largos viajes "oceánicos" fueran señalados como un mecanismo mediante el cual agentes "civilazadores" venidos desde tierras distantes, com un mayor nivel de desarrollo sociocultural, hicieron entrega de aparataje tecnológico y empleo de técnicas a otros grupos com niveles supuestamente más "atrasados" (Carabias 2000: 31).

Essas evidências dizem respeito a uma série de representações de pirogas (Figs. 3 a 7) classificadas como da tradição nordeste, que foram pintadas em abrigos sob rocha da região do Seridó, no interior do estado do Rio Grande do Norte. Tradição que, segundo Borges (2008: 12), teria permanecido na região entre $12.000 \mathrm{e}$ 6.000 anos AP.

Ainda que a autora Martin (1997) faça referência a pirogas, uma análise direcionada ao tema náutico sugere não somente a possibilidade de tais pinturas representarem canoas

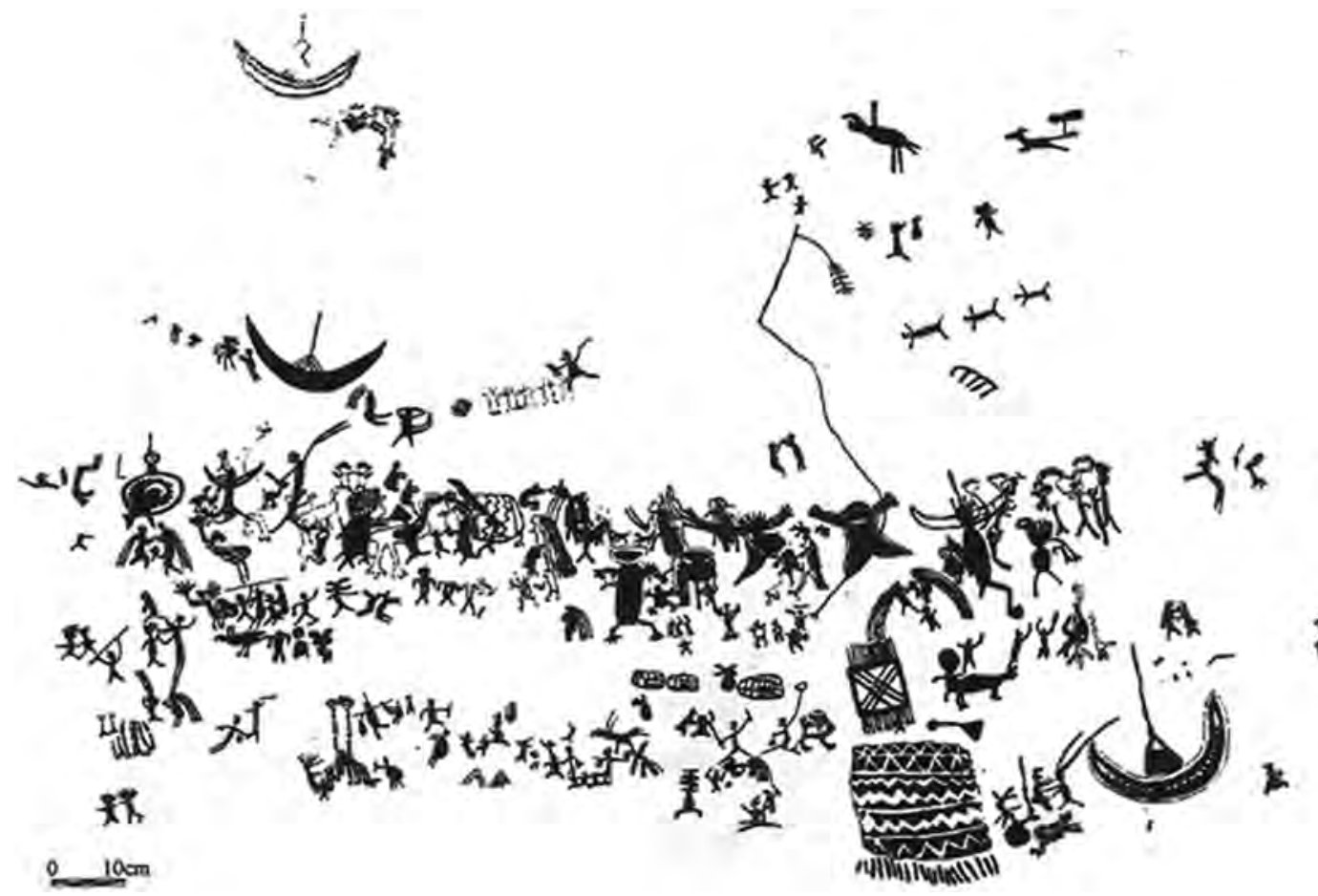

Fig. 3. Painel Casa Santa, Carnaúba dos Dantas, RN (Tradição Nordeste, sub-tradição Seridó) (Martin 1997: 262). 
O surgimento da navegação entre os povos dos sambaquis: argumentos, hipóteses e evidências.

R. Museu Arq. Etn., São Paulo, n. 21, p. 31-49, 2011.

monóxilas, mas, principalmente, em função de seu formato semilunar, indicarem canoas de feixes de junco ou de casca de árvore. Nestas representações é possível ainda identificar uma recorrência de elementos acessórios, os quais poderiam estar relacionados a adaptações ou inovações tecnológicas decorrentes da experimentação e contínuo desenvolvimento destas embarcações.

Além de possíveis mastros e de uma utilização que não está necessariamente vinculada

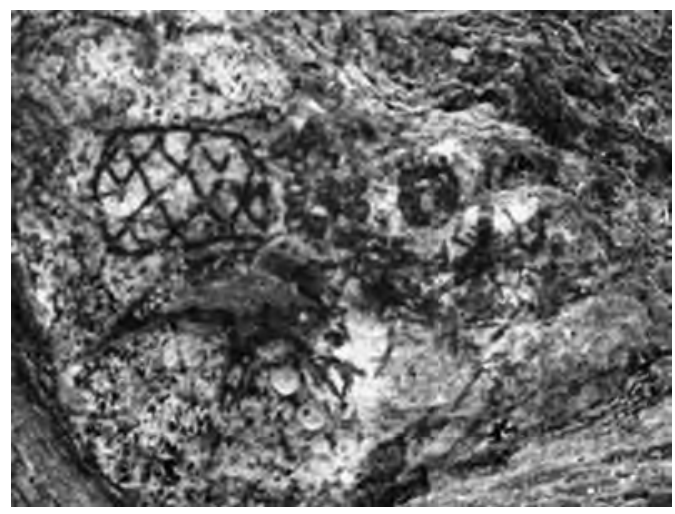

à subsistência (Fig. 8 - c), as representações sugerem ainda a possibilidade da utilização de algum tipo de velame (Fig. 8 - g). Mesmo que esse tipo de forma de representação geométrica seja comum nos sítios da região e, nesse sentido, uma interpretação equivocada possa ser estabelecida a partir da sobreposição de diferentes figuras, a sua associação com um dos mastros reforça ainda mais a hipótese de este elemento representar uma canoa com algum tipo de propulsão a vela.

Figs. 4 e 5. Prováveis representações de pirogas (classificadas como da tradição nordeste) (foto: Flávio Calippo).

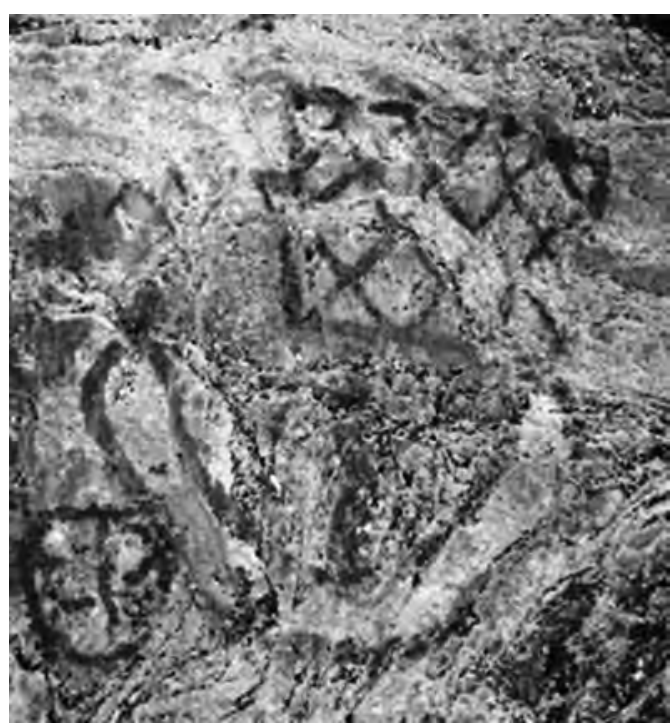

Figs. 6 e 7. Prováveis representações de pirogas (classificadas como da tradição nordeste). pintadas em abrigos sob rocha da região do Seridó, interior do Rio Grande do Norte (foto: Flávio Calippo).

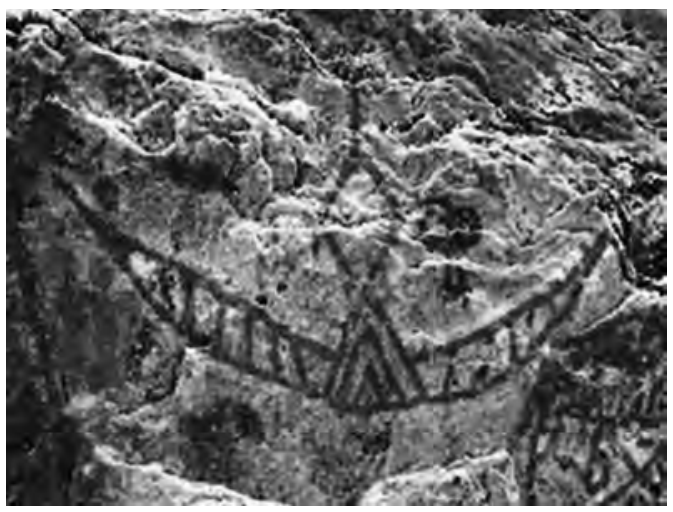

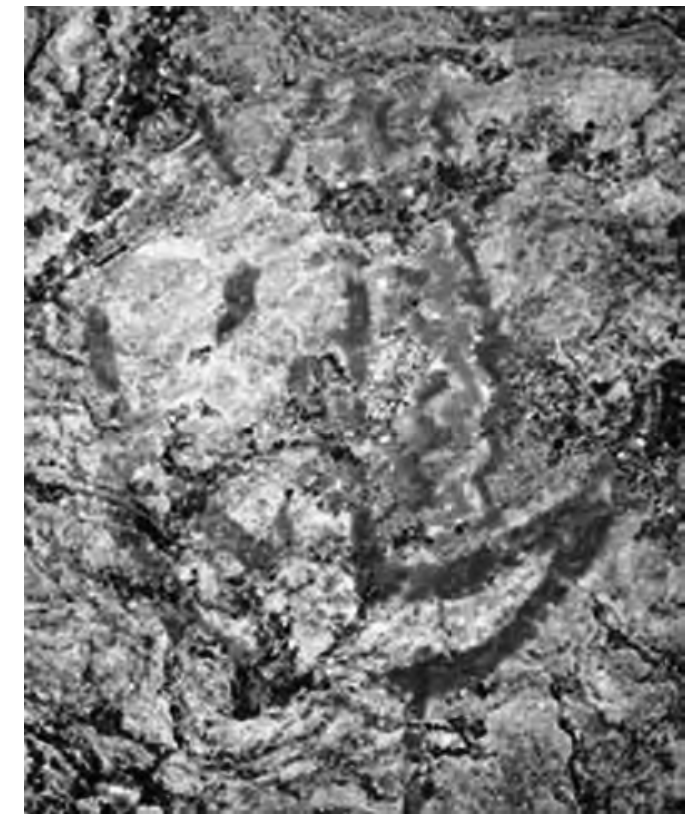


Embora aqui se defenda a possibilidade de essas representações serem relativas a canoas já com certos tipos de inovações (mastros, velas etc.) ou com adaptações desenvolvidas para a realidade local, anos mais tarde, segundo Borges (2008: 52), Gabriela Martin e Anne Marie Pessis apontaram, com base em análises etnográficas comparativas, a possibilidade de essas imagens também serem representações de redes funerárias. esse tipo de grafismo ser uma questão bastante controversa, que, no mínimo, demandaria um estudo específico dessa questão, existem algumas características que nos permitem hipotetizar a respeito da utilização de embarcações associadas ao contexto ar-
Apesar de a atribuição de significados a

queológico da região do Seridó. Além de as prováveis representações de velas se encontrarem recorrentemente associadas às canoas e a possíveis mastros, essas velas apresentam aparentemente um padrão diferenciado do encontrado nas outras figuras geométricas (com franjas) que se distribuem pelos painéis dos sítios da região (Fig. 3). Por outro lado, ainda que tais figuras não pudessem ser assim consideradas, tendo o tema náutico como referência, talvez possam representar a utilização de redes de pesca.

Mesmo que ainda não se possa ter uma noção mais específica e precisa para essa questão, existe outro fator que fomenta o entendimento de representações como canoas: o contexto paleoambiental da região do Seridó. Segundo Borges (2008: 66), a região é marcada por

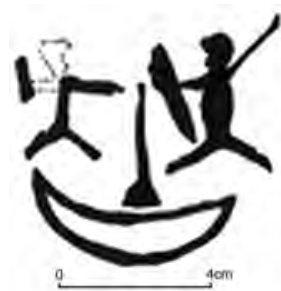

a)

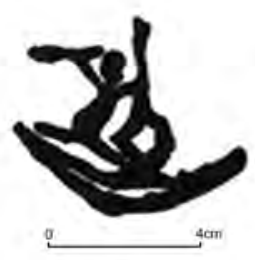

d)

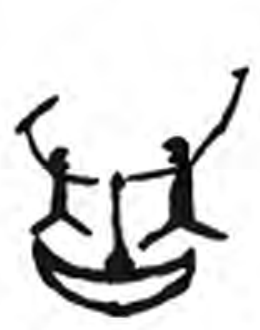

h)

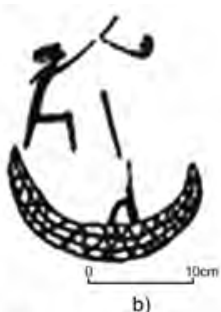

b)

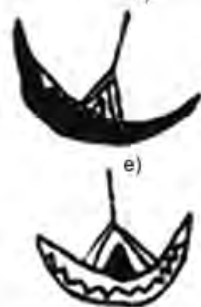

f)

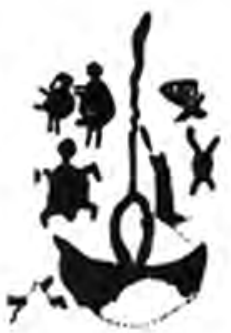

$\underbrace{200 m}_{11}$
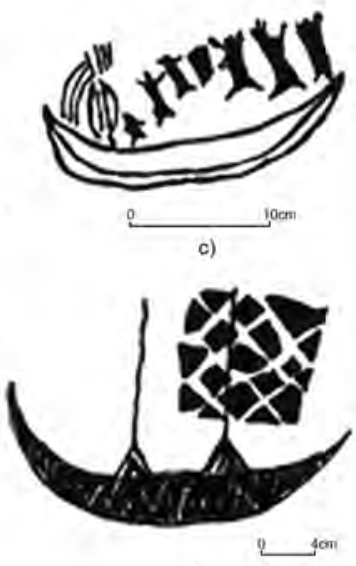

g)

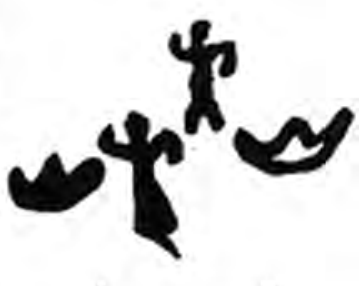

Fig. 8. Representações de pirogas encontradas no sítio Pedra do Alexandre, em Carnaúba dos Dantas. (c) representação de uma piroga que carrega sete indivíduos guiados por um chefe que ostenta longo cocar de penas; (g) provável representação de uso de vela) (Martin 1997: 263). um relevo acentuado, através do qual se desenvolve uma hidrografia intermitente, pela qual os rios da região só assumem seus volumes máximos ao longo das épocas chuvosas. No entanto, segundo essa autora, diversas evidências arqueológicas (registros rupestres e vestígios alimentares) sugerem a predominância, no passado, de um ambiente entremeado por um regime hídrico mais proeminente do que o atual.

Quando aborda a questão da origem da ocupação do sertão do Seridó, em ambas as hipóteses que propõe (via rios interiores ou a partir do litoral), o ambiente aquático é sempre o principal elemento de conexão.

Uma situação semelhante foi apresentada por Carabias (2000: 40), ao abordar a questão da origem das balsas utilizadas para navegação oceânica pré-histórica ao longo da costa pacífica: 


\begin{abstract}
Evidencias arqueológicas apuntam a contactos marítimos periódicos entre el litoral ecuatoriano y Mesoamérica desde el Periodo Formativo Temprano, em tempos tan antiguos como La fase Valdivia Tardia (ca. 2.000-1.500 a.C.), pero se cree que los pré-cerámico Valdivia que arribaron al lugar, ya poseían embarcaciones de alta mar (ca. 3.400 a.C.)(Zeidler 1986). Buse (1973) há postulado que las balsas de madera se genaron en los rios interiores del Perú, sufriendo una posterior adaptación marítima (Carabias, ibidem: 40).
\end{abstract}

\section{Reinterpretando alguns artefatos ligados à pesca e à navegação}

Tendo como referencial a possibilidade de que a tecnologia náutica tenha se dispersado a partir do interior, como apontado anteriormente pelas evidências por Carabias (2000) e, provavelmente, pelas pinturas da região do Seridó, serão aqui apontadas e discutidas as probabilidades de alguns artefatos sambaquieiros poderem ter uma outra função do que a inicialmente interpretada. Como o arcabouço teórico utilizado para a interpretação dessas evidências fundamentava-se em uma proposta desenvolvida inicialmente para se estudar povos do interior, é provável que a partir de um olhar específico das populações costeiras se possam indicar usos diferentes para esses mesmo objetos.

Embora as hipóteses que vêm sendo consideradas neste artigo, para explicar o surgimento da navegação entre os sambaquieiros, pareçam sempre apontar no sentido do interior para o litoral, este fluxo ainda não está bem definido. Devido à complexidade dessa discussão, não abordaremos aqui outras possibilidades. Porém, é importante ressaltar que as populações sambaquieiras possam ter surgido no litoral, provavelmente, a partir de grupos caçadores coletores que, com a elevação do nível relativo do mar a partir de 18.000 anos AP, teriam deparado com o surgimento das amplas estuarinas de que hoje conhecemos apenas uma pequena parte. Ainda que, na última década, evidências concretas venham sendo localizadas ao longo da costa do continente americano (Calippo 2010), a comunidade científica ainda vê essa hipótese com desconfiança porque a maioria dessas áreas encontra-se submersa.

Nesse sentido, para discutir a possibilidade das origens da apropriação dos ambientes aquáticos por parte dos sambaquieiros, trabalharemos aqui com a hipótese de que as tecnologias náuticas, independentemente do sentido da ocupação humana, tenham se dado no sentido do interior em direção ao litoral. Pois, é isso que, em uma primeira análise, parecem apontar as evidências hoje conhecidas (que ainda não levam em consideração a possível ocupação das áreas que foram submersas pela elevação do nível relativo do mar).

Do mesmo modo que a primeira proposta, a hipótese da chegada dos sambaquieiros fundamenta-se, principalmente, no entendimento de que os povos dos sambaquis se originaram a partir de uma mudança no modo de vida de populações caçadoras e coletoras que habitavam uma região da margem continental brasileira que atualmente se encontra submersa.

Essa possibilidade se apoia fundamentalmente na hipótese de que a ocupação do litoral tenha se dado a partir do deslocamento das populações caçadoras coletoras através das principais bacias hidrográficas da região sul e sudeste, utilizando os rios como elementos de conexão entre o planalto e as antigas planícies fluviais que, entre 18.000 e 7.000 anos AP margeavam o Oceano Atlântico.

Mesmo ainda não sendo possível estabelecer um quadro cronológico de sítios que apontem essa migração em direção ao litoral, existem ao longo do registro arqueológico dessas populações caçadoras alguns indícios que podem sugerir o desenvolvimento de uma adaptação, cada vez maior, ainda em locais distantes do litoral, aos ambientes aquáticos. Resultado, provavelmente, do contato que esses grupos caçadores acabaram desenvolvendo a partir da exploração dos ambientes dos vales e dos rios que utilizavam para se deslocar (ou migrar) em direção ao litoral ou às extensas planícies fluviais do início do holoceno. Em meio às quais, mais tarde, desenvolveu-se um novo e promissor ambiente costeiro. 
Dentre essas evidências de captação de recursos aquáticos, podemos destacar, por exemplo, a ocorrência de pontas serrilhadas (Fig. 9), específicas para a prática de pescarias, localizadas no interior do Rio Grande do Sul (abrigo sob rocha Garivaldino - RS-TQ:58). Segundo Mentz Ribeiro e Torrano Ribeiro (1999), apesar de o uso dessas pontas atingirem seu ápice por volta do ótimo climático, sua produção já havia se iniciado em períodos anteriores aos 8.000 anos AP. Nos primeiros momentos do sítio (Período I), cujas idades estão entre 9.000 e 8.000 anos AP, as pontas serrilhadas equivalem a apenas $1,3 \%$ do total das pontas de projétil. A partir do qual, aumentam de número em direção ao presente, chegando a representarem $4 \%$ e $18 \%$, entre, respectivamente, aproximadamente 8.000 e 7.250 (ou 6.000) anos AP (Período II) e entre 6.000 e 1.000 anos AP (Período III).

No caso deste sítio, com datas que remetem sua ocupação a por volta de $9.430 \pm 360$ anos AP (Beta-44739), ocorrem ainda dentes de tubarão, pinças de crustáceos (Fig. 10) e conchas de origem marinha. Indicando, assim, já nesses primeiros momentos, algum contato (por mínimo que seja) entre esses grupos, os ambientes aquáticos do interior e os ambientes costeiros.

Além do caso das pontas serrilhadas, existem também outros instrumentos, tradicionalmente associados à caça, que, se analisados a partir de contextos costeiros e marítimos, podem ser também interpretados como artefatos utilizados na pesca ou até mesmo na caça e na pesca simultaneamente. Nesse sentido, Stewart (1982) aponta, por exemplo, com base no estudo de artefatos dos índios da costa noroeste dos Estados Unidos, que existe uma série de instrumentos, comumente atribuídos a caçadores, que são atualmente utilizados em atividades de pesca por populações indígenas atuais (Fig. 11). Esse é o caso de bolas de boleadeira, pingentes e outros artefatos, que tanto poderiam servir para a função que lhes dá o nome como serem utilizados (ou também utilizados) como pesos de rede e de anzóis.

Uma situação que não é verificada somente por Stewart (1982) nas Américas. Cleyet-Merle (1990) descreve, também, uma situação semelhante para sítios pré-históricos e não para o período greco-romano francês (Fig. 12).

Exemplos desse tipo também são encontrados no Brasil. Em Mentz Ribeiro e Calippo (2000) podemos encontrar uma série de tipos de pontas em osso (Fig. 13), que, na realidade, tanto poderiam ser utilizadas
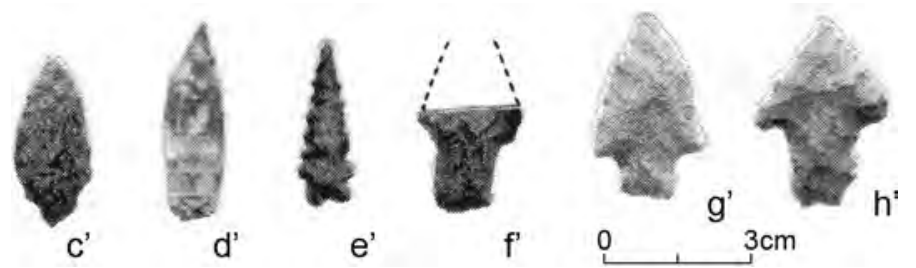

Fig. 9. Ponta de projétil (e) serrilhada encontrada no abrigo sob rocha Garivaldino (RS-TQ:58), entre as camadas arqueológicas associadas ao Período I (Mentz Ribeiro e Torrano Ribeiro 1999: 52).

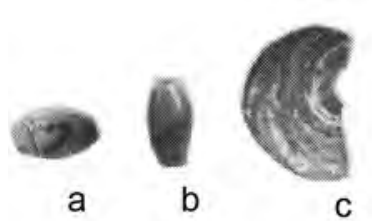

Fig. 10. Dentes de Tubarão (d, e) e conchas costeiras (a, b, c) associados ao Período III e pinças de crustáceos marinhos $(\mathrm{g}, \mathrm{h})$ relativos ao Período II (Mentz Ribeiro e Torrano Ribeiro 1999: 59 e 65). como pontas (pontas de projétil, furadores etc.) ou de modo a servirem para a confecção de anzóis, como indicado (abaixo) por Cleyet-Merle (1990) para os sítios franceses (Figs. 14 e 15). De modo similar, nos sítios dessa região, é provável ainda que alguns machados, pingentes e peças de uso desconhecido também pudessem ser utilizados, no âmbito náutico e pesqueiro, como pesos de rede, pesos para anzóis e enxós (Fig. 16).

Sob essa perspectiva, existe outro exemplo que não pode deixar de ser mencionado: o dos machados e politores fixos. Esses instrumentos poderiam também ser reinterpretados no sentido de serem ferramentas específicas 


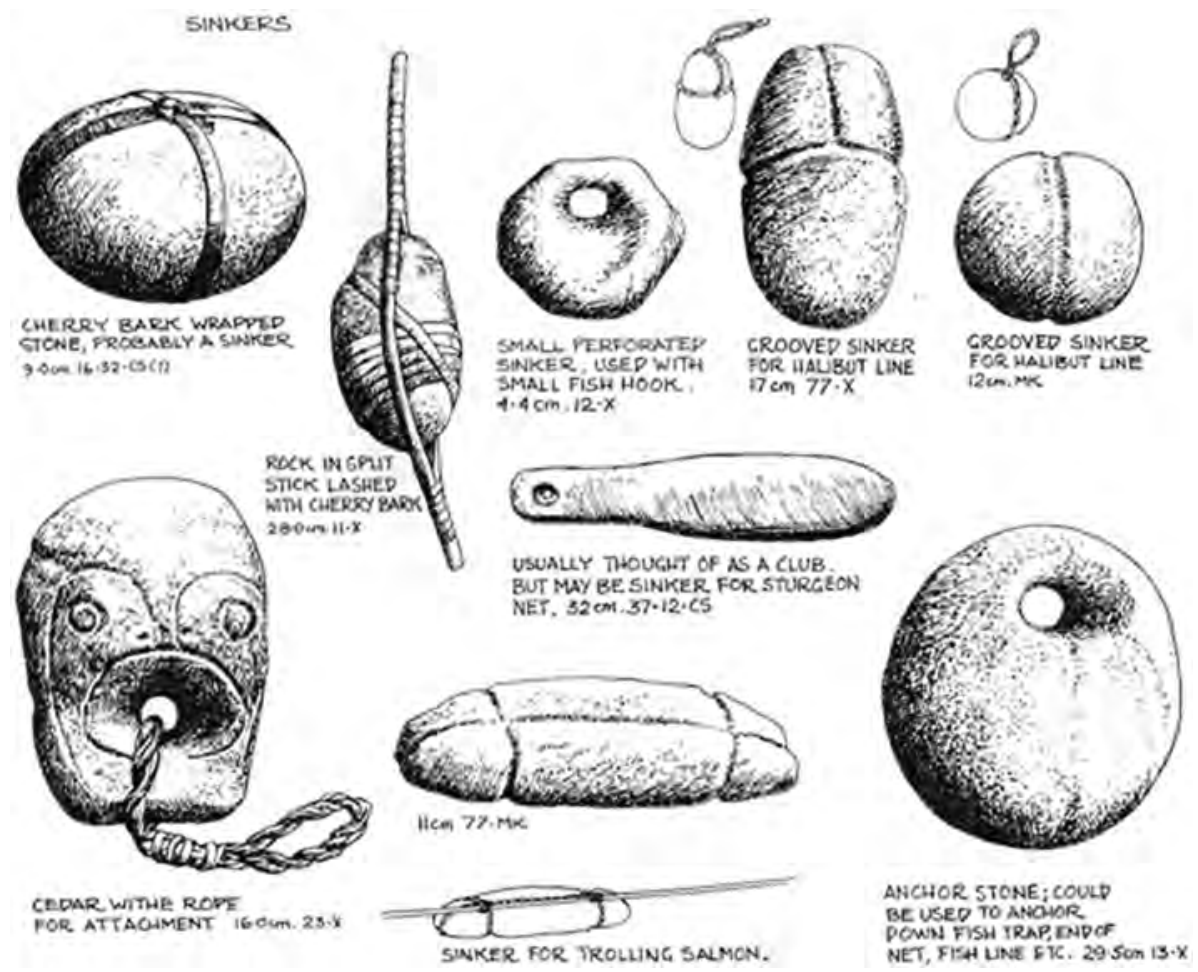

Fig. 11. Pesos de rede, utilizados por populações indígenas norte americanas, os quais apresentam similaridades com artefatos tradicionalmente associados, na Arqueologia brasileira, a instrumentos de caça (Stewart 1982:31).
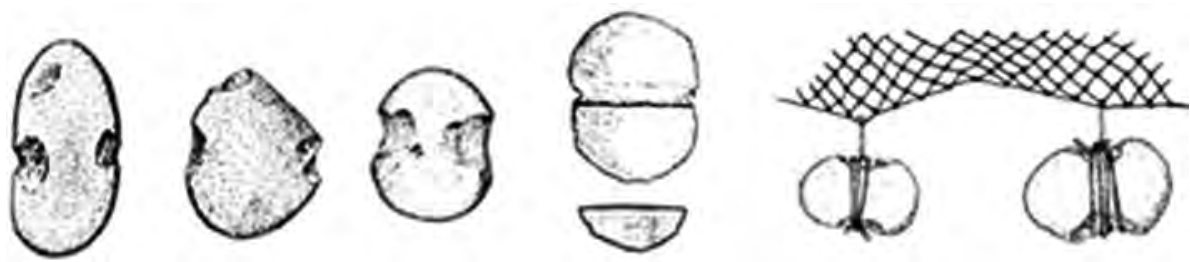

Fig. 12. Diferentes tipos de peso de rede (dos períodos pré-histórico, galo romano e atual) provenientes da França (Cleyet-Merle 1990: 146).

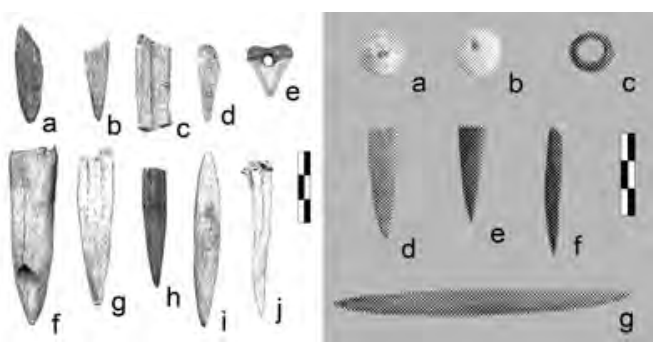

Fig. 13. Artefatos de osso (polido), inicialmente identificados como pontas de osso que, no entanto, poderiam ser utilizadas como anzóis (sambaquis do litoral centro e sul do Rio Grande do Sul) (Mentz Ribeiro e Calippo 2000: 20 e 21). (ou principalmente utilizadas) para a fabricação de canoas. Para Tenório (1999), por exemplo, existe um vínculo entre a produção das lâminas de machado e a confecção de canoas:

Ao que tudo indica, a pesca era desenvolvida com a utilização de canoas. Chegamos a essa conclusão pela importância das lâminas de machado para os habitantes do sítio, bem como pelas alterações nos ossos dos membros inferiores dos esqueletos encontrados, resultantes, provavelmente de um esforço 

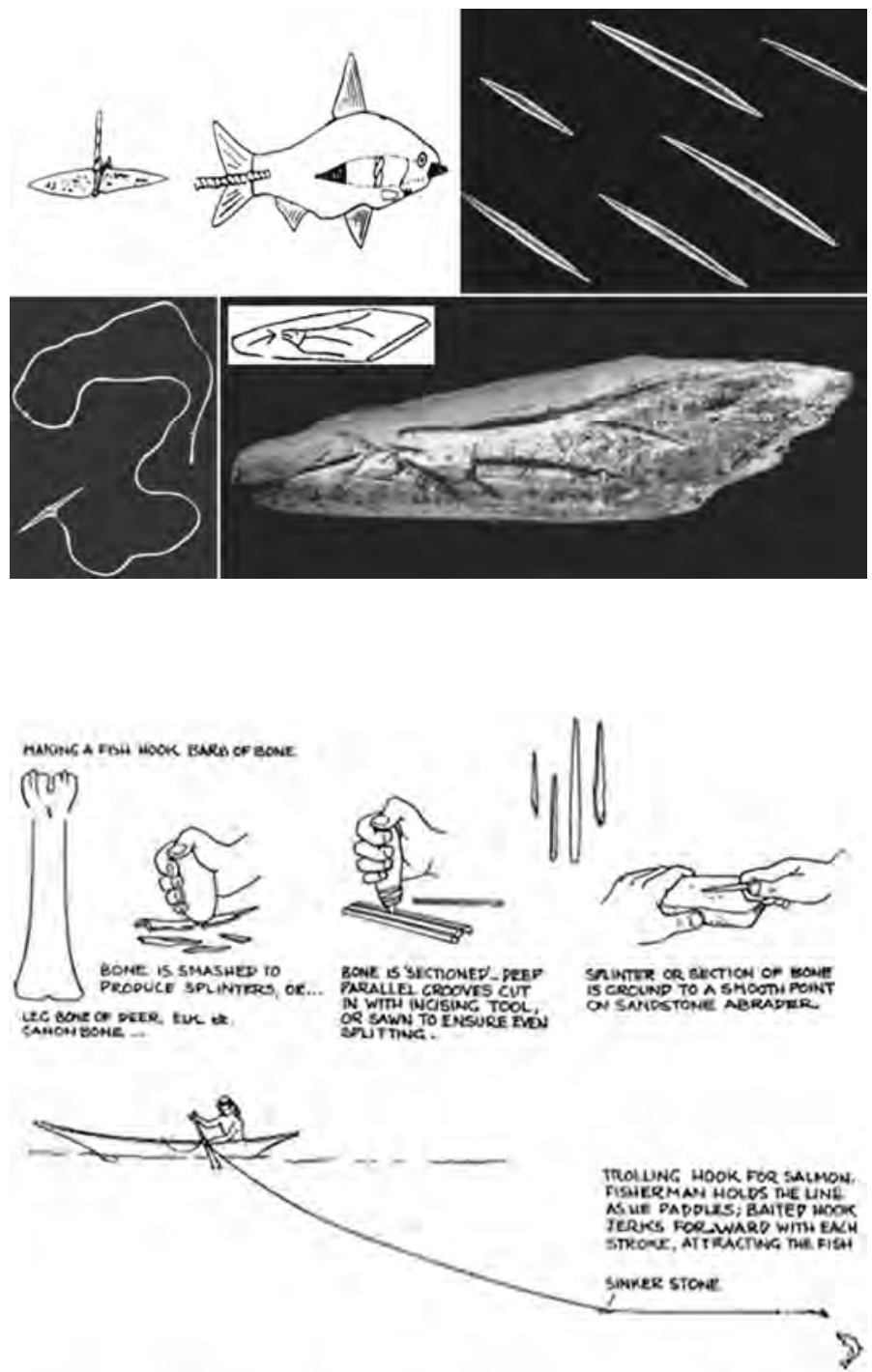

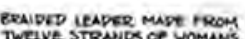
IONG MAIR is NeNG-Wivisiois To Sumion at kT

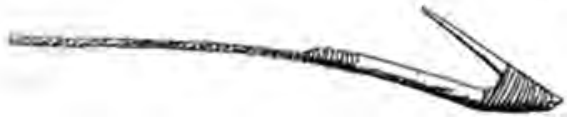

Fig. 15. Esquema da preparação e a utilização de anzóis em osso (Stewart 1982: 36 e 41).
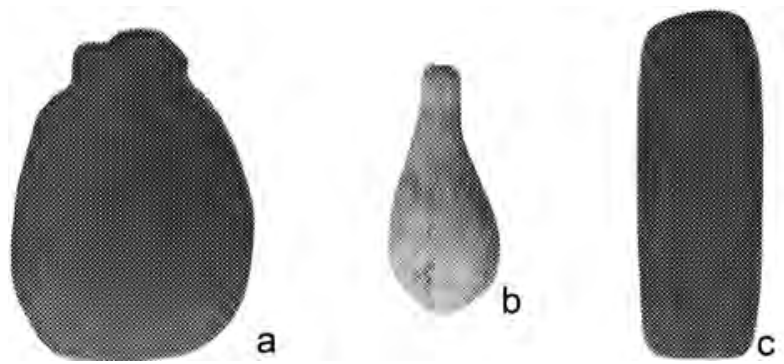

Fig. 14. Na porção superior, esquema para utilização em anzol (esquerda) e anzóis de osso. Na porção inferior, anzol de madeira atualmente utilizado no sudoeste da França, e gravura, sobre galhada de rena, que representa um peixe engolindo um anzol, relativa ao magdaleniense francês (direita) (CleyetMerle 1990: 79, 85 e 86).
Fig. 16. Pingentes (a e b) e peças de uso desconhecido (c), encontrados nos sambaquis do litoral centro e sul do Rio Grande do Sul, que também poderiam ser utilizados na atividade pesqueira como pesos de rede (a) e pesos para anzóis (a e b) (Mentz Ribeiro e Calippo 2000: 21). 
constante de remar em pé. Acreditamos que a lâmina de machado fosse utilizada predominantemente na elaboração das canoas (Tenório 1999: 239).

\section{Embora concordemos com a autora a} respeito da existência de um forte vínculo entre as bacias de polimento e a fabricação das canoas, acreditamos, por outro lado, que as bacias de polimento não estariam associadas ao surgimento da navegação e, sim, a um período e a um local onde a utilização dessa tecnologia intensifica-se e desenvolve-se; gerando, provavelmente, não só um aumento na quantidade de canoas produzidas, mas, principalmente, o desenvolvimento de novas tecnologias específicas à construção naval.

Como evidência do desenvolvimento dessas novas tecnologias, apontamos o caso de alguns machados em que, segundo Semenov (1970), após uma cuidadosa análise, foram identificadas diversas marcas de uso que permitiram atribuir a essas ferramentas líticas a função de enxós ${ }^{4}$ (Fig. 17).

Ainda que esse tipo de estudo não tenha sido realizado nos artefatos provenientes dos sambaquis, não podemos deixar de destacar tal hipótese. Devido ao grande número de bacias de polimento, o mais provável é que instrumen-
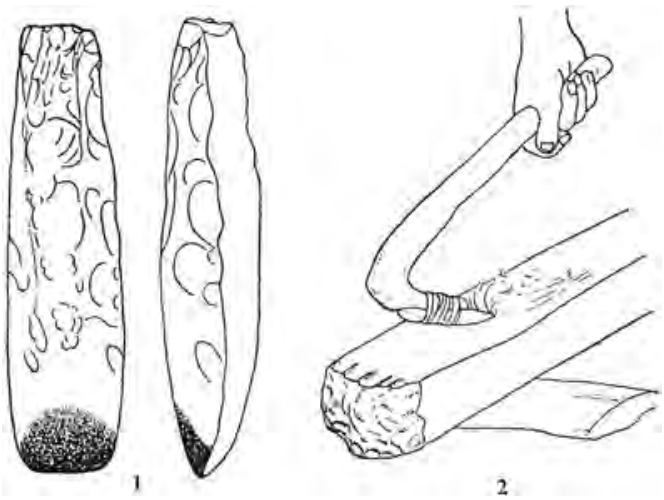

Fig. 17. Duas vistas de um enxó (com as áreas desgastadas pelo uso) (esquerda) e uma em utilização (Semenov 1970: 135).

(4) Ferramentas normalmente utilizadas para a escavação do interior de canoas monóxilas.

tos desse tipo comecem a ser identificados à medida que as coleções forem revistas. Enxós e machados são diferenciados com base na simetria e na inclinação das estrias que se desenvolvem a partir do gume. As quais se formam em consequência das diferentes inclinações com que, em cada uma dessas ferramentas, o gume e o objeto atingem a madeira (Semenov 1970: 127) (Fig. 18).

An axe is recognized by its symmetrical profile, an adze or hoe by its asymmetry, and a chisel by its small size. Adzes can be straight or convex (Semenov 1970: 126).

Enquanto nos machados predominam estrias inclinadas em ambos os lados e as bordas da lâmina tendem a estar desgastadas (Fig. 19), nos enxós, por outro lado, as estrias tendem a ocorrer de forma perpendicular ao gume e de maneira assimétrica em relação a seus lados (Fig. 20).

Ainda que a identificação de enxós seja um argumento interessante para começarmos a refletir sobre a possibilidade da especialização náutica, é possível que eles não tenham surgido no momento da origem das técnicas de fabricação dos equipamentos de navegação sambaquieiros. Nesse caso, o mais provável é que, no início, os próprios machados foram as principais ferramentas utilizadas e, a partir da experimentação e de sua utilização para a elaboração de equipamentos flutuadores mais simples (troncos, jangadas, canoas de casca de árvore

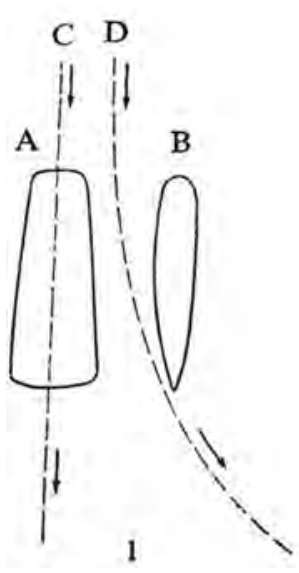

Fig. 18. Esquema dos ângulos de incidência de um enxó sobre a madeira (Semenov 1970: 126). 


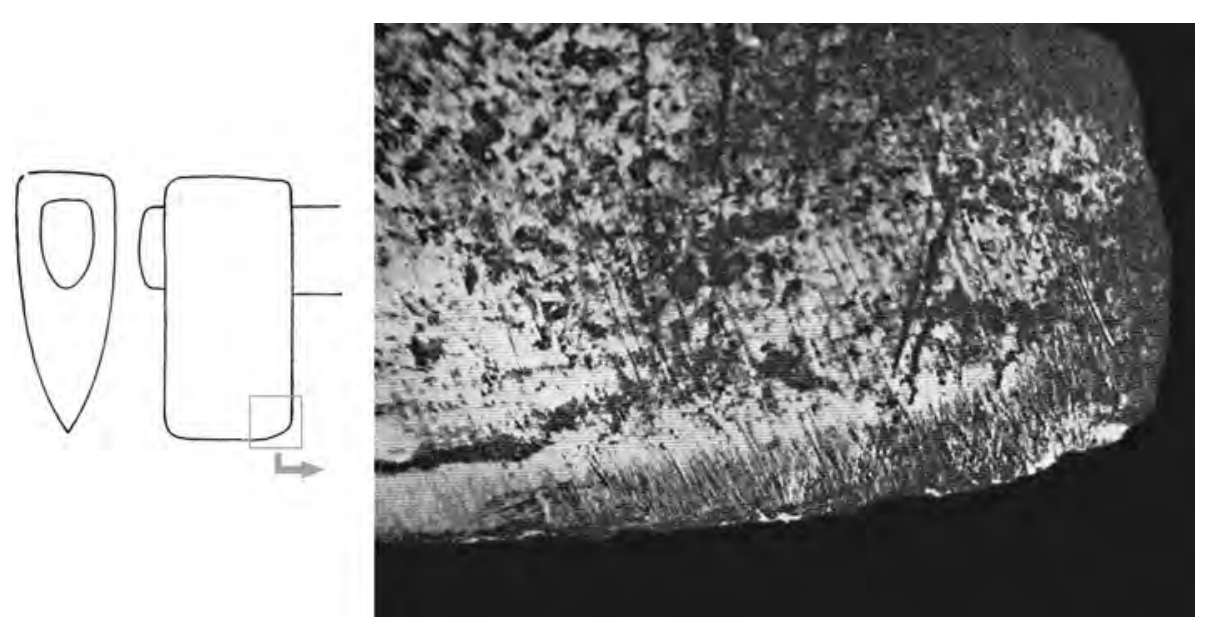

Fig. 19. Desenho esquemático e detalhe da borda de um machado, onde se pode verificar a predominância de formas simétricas (esquerda) e a inclinação das estrias em relação ao gume (direita) (Semenov 1970: 124).
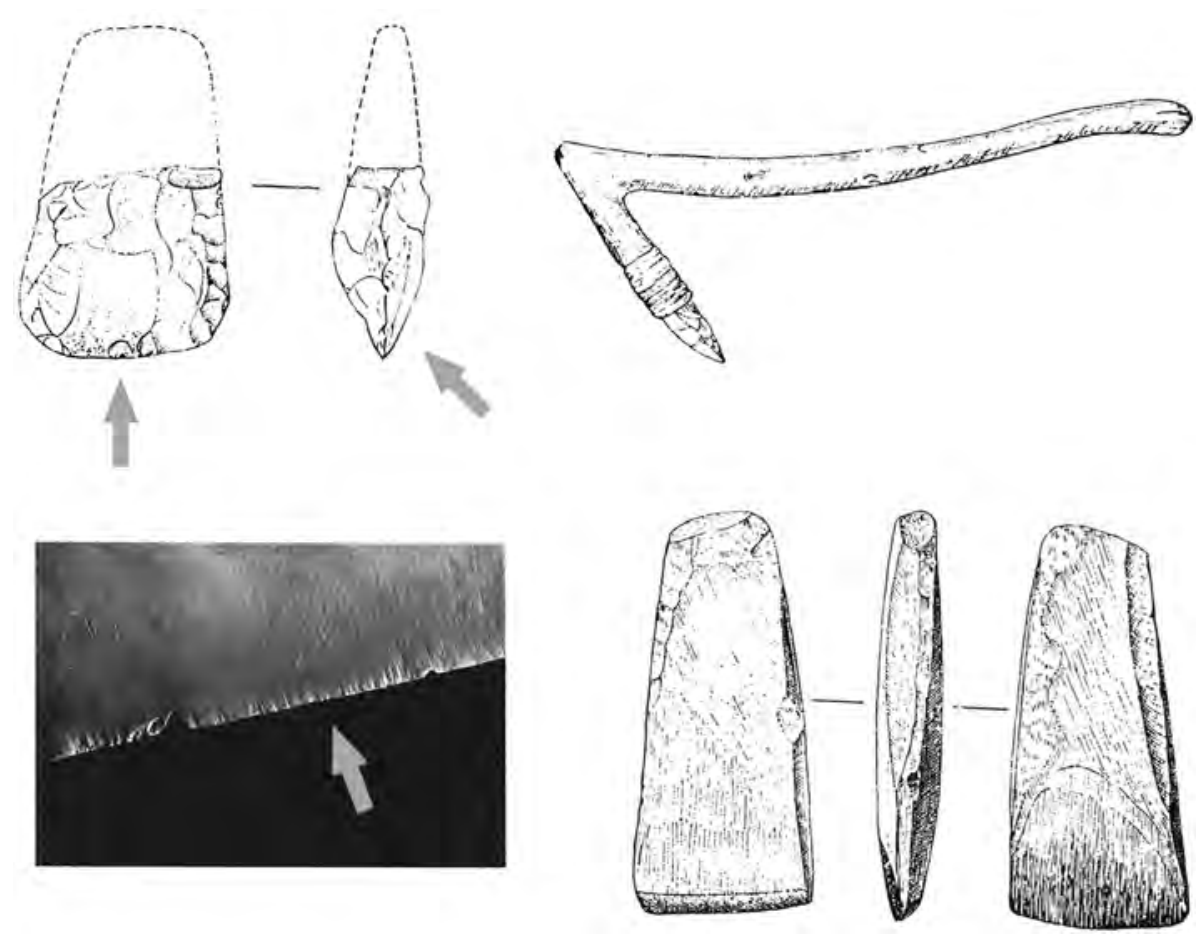

Fig. 20. Desenho esquemático e detalhe da borda de um enxó, onde pode-se verificar a predominância de estrias perpendiculares ao gume e a sua assimetria em relação a ambos os lados (Semenov 1970: 127).

etc.), a serem empregados nos ambientes mais protegidos (rios, estuários, lagos e lagoas), é que tenham surgido os enxós.
Somente com a consequente exploração de novos ambientes em direção ao exterior dessas regiões mais tranquilas (áreas costeiras e mari- 
nhas), é que surgiria a necessidade do desenvolvimento de embarcações mais adequadas à navegação através de ondas e contra correntes marinhas Nesse processo, além do desenvolvimento de canoas mais complexas, surgiriam também as ferramentas para sua elaboração. Inovações úteis não só para a derrubada da árvore e sua escavação, mas também para a preparação de superfícies e contornos mais simétricos e hidrodinâmicos.

Esse parece ser o contexto em que se inserem as bacias de polimento do norte do estado de São Paulo e sul do Rio de Janeiro. Uma vez extrapolados os limites das áreas lagunares que ocorrem principalmente ao longo do litoral sul de São Paulo e central do Rio de Janeiro (marcados também pela presença dos sítios mais antigos), as comunidades sambaquieiras passaram a especializar-se na exploração dos ambientes costeiros e marinhos abertos, para os quais seria fundamental a utilização de canoas mais rápidas e manobráveis, que fossem capazes não só de transportar pessoas, conchas e pescado, mas, principalmente, todos os conjuntos de materiais provenientes de terra. Nas ilhas, além da água (que muitas vezes não existe nas ilhas), deve-se considerar também a questão do culto aos mortos, os quais deveriam ser também transportados através das canoas para serem enterrados nos sítios insulares.

Tal compreensão leva-nos a pensar na hipótese de que a navegação não teria somente propósitos econômicos. Neste sentido, não seria estranho supor que a exploração e a apropriação desses novos ambiente fizessem com que eles passassem, cada vez mais, a compor, também, o universo cultural ou simbólico dos sambaquieiros. À medida que as canoas passaram a fazer parte desse contexto funerário, simbolizando, possivelmente, "uma viagem, uma travessia dos vivos ou dos mortos" (Amenomori 2005: 132), se abre para a prática da navegação um universo que extrapola seu uso como elemento de transporte e obtenção de recurso.
A canoa era o seu meio de locomoção, de circulação, seu referencial de visualização da paisagem para a escolha do local de enterramento e seus rituais, isto é, o seu meio de vida, sem a qual esses grupos não conseguiriam ocupar áreas tão distantes do continente e áreas costeiras tão recortadas com a Serra do Mar penetrando até o mar (Amenomori 2005: 141).

Nesse sentido, como apontado por Malinowski, em relação ao kula praticado pelas sociedades insulares tobriandesas, a navegação entre as ilhas e os conjuntos de sítios sambaquieiros poderia atuar como um elemento de conexão entre as comunidades, reforçando, talvez, uma identidade sambaquieira e compartilhando valores, conhecimentos, percepções e novas tecnologias.

\section{Conclusão}

Com base nas hipóteses e nos dados aqui discutidos a respeito da relação dos primeiros habitantes do litoral brasileiro com os ambientes aquáticos, não podemos mais deixar de considerar a existência de evidências arqueológicas a esse respeito. Embora alguns desses argumentos, hipótese e evidências ainda apresentem pontos a serem mais bem explorados, sabemos que existe uma abordagem teórica que é capaz de identificar e compreender tais evidências. Este artigo representa um primeiro olhar que se direciona a essas questões.

Para darmos continuidade a tal discussão o que precisamos é daqui para frente olhar para os povos dos sambaquis a procurar também compreendê-los a partir de uma relação dialética com os ambientes aquáticos, onde os indivíduos, ao interagirem com esse meio, tanto alteraram os ambientes costeiros como passaram por experiências que os modificaram individual e coletivamente. Um processo que, provavelmente, deixou vestígios e pode indicar as percepções e as estratégias que os sambaquieiros desenvolveram para dominar os ambientes costeiros e aquáticos. 
CALIPPO, F.R. The rising of navigation in the sambaqui people: arguments, hypotheses and evidences. R. Museu Arq. Etn., São Paulo, n. 21, p. 31-49, 2011.

\begin{abstract}
The archaeological evidence found along the Brazilian coast indicate that this area was occupied since, at least, 8,000 years BP by collecting groups which exploited the coastal aquatic environment. Though the scientific community hold that the 'sambaquieiros' were skillful navigators, evidences for that are still rare. In this article, starting from an approach focused on Maritime Archaeology, arguments, hypotheses and evidences which discuss the understanding that, beyond a strong economical and symbolical relation with the aquatic environment, the people of the sambaquis either appropriate or developed techniques of navigation and nautical artifacts.
\end{abstract}

Keywords: Maritime Archaeology - Sambaquis - Prehistoric navigation.

\title{
Referências bibliográficas
}

ADAMS, J.

2002 Maritime Archaeology. In: Charles E. Orser, Jr., Ch. E. (Ed.) Encyclopedia of Historical Archaeology. London, Routledge: 328-330.

AMENOMORI, S. N.

2005 Paisagem das ilhas, as ilhas da paisagem: A ocupação dos grupos pescadores-coletores pré-históricos no litoral norte do estado de São Paulo. Tese de Doutorado em Arqueologia. São Paulo, Museu de Arqueologia e Etnologia, Universidade de São Paulo.

BLOT, J-Y.

1999 O mar de Keith Muckelroy: o papel da teoria na arqueologia do mundo náutico. Al-Madan, Almada, Centro de Arqueologia, série 2, 8: 41-55.

BORGES, C.C.L.

2008 Uma narrativa pré-histórica. O cotidiano de antigos grupos humanos no sertão do Seridó/RN. Tese de Doutorado em HistóCALIPPO, F.R. ria. Assis, Universidade Estadual Paulista.

2010 Sociedade Sambaquieira, Comunidades Maritimas. Tese de Doutorado em Arqueologia. São Paulo, Museu de Etnologia e Arqueologia, Universidade de São Paulo.

2011 Sociedade Sambaquieira, Comunidades Marítimas. Revista de Arqueologia, Sociedade de Arqueologia Brasileira, 34: 1-20.
CAPASSO, L.; KENNEDY, K.A.R.; WILCZAK, C.A.

1999 Atlas of Occupational Markers on Human Remains. Teramo: Edigrafital S.P.A.

CARABIAS, D.

2000 Navegación prehispánica en el Norte de Chile: uma contribución al estúdio de las práticas náuticas em las áreas Andes Centro-Sur y Meridional. Revista Werkén, Santiago, 1: 31-53.

CARVALHO, C.R.

2004 Marcadores de estresse ocupacional em populações sambaquieiras no litoral fluminense. Tese de Doutorado em Saúde Pública. Rio de Janeiro, Escola Nacional de Saúde Pública.

CHAPLIN, J.M.; STEWART, I.A.

1998 The prevalence of exostoses in the external auditory meatus of surfers. Clin Otolaryngol, 23-24: 326-330.

CLEYET-MERLE, J-J.

1990 La Prehistoire de la Peche. Paris: Editions Errance.

DIEGUES, A.C.S'A.

1998 Ilhas e mares: simbolismo e imaginário. São Paulo: Editora Hucitec.

2000 Os ex-votos marítimos da sala de milagres da Basílica do Senhor Bom Jesus de Iguape, São Paulo. In: Diegues, A.C.S’A. (Org.) A imagem das águas. São Paulo: Hucitec: 157-207. 
DURAN, L.D.

2008 Arqueologia Marítima de Um Bom Abrigo. Tese de Doutorado em Arqueologia. São Paulo, Museu de Etnologia e Arqueologia, Universidade de São Paulo.

FONTENOY, P.

1998 A Discussion of Maritime Archaeology. In: Babits, L.; Tilburg, H.V. (Eds.) Maritime Archaeology - A Reader of Substantive and Theoretical Contributions. New York: Plenum Press (The Plenum Series in Underwater Archaeology).

HAWKEY, D.E.; MERBS, C.F.

1995 Activity-induced musculoskeletal stress markers (MSM) and subsistence strategy among ancient Hudson Bay Eskimos. International Journal of Osteoarchaeology, 5: 324-338.

HORNELL, J.

1970 Water Transportation: origins \& early evolution. Newton Abbot: David \& Charles.

KENNEDY, G.E.

1986 The relationship between exostoses and cold water: a latitudinal analysis. Am. J. Phys Anthrop, 71-74: 401-415.

LISIANSKY, U.

1814 A Voyage Round the World in the Years 1803, 4, 5, Ë 6; Performed by Order of His Imperial Majesty Alexander the First, Emperor of Russia in the Ship Neva. London: Printed for John Booth; and Longman, Hurst, Rees Orme \& Brown

LLAGOSTERA, A.

1990 La navegación prehispánica en el Norte de Chile: bioindicadores e inferencias teóricas. Chungará, 24-25: 37-51.

MALINOWSKI, B.

1984 Argonautas do Pacífico Ocidental. Um relato do empreendimento e da aventura dos nativos nos arquipélagos da Nova Guiné Melanésia. São Paulo: Ed. Abril Cultural.

MARTIN, G.

1997 Pré-História do Nordeste do Brasil. Vol. 1, 2a ed. Recife: Universitária da UFPE.

MARTIN, G.

1997 Pré-História do Nordeste do Brasil. Vol. 1, 2a . ed. Recife: Universitária da UFPE.

MENTZ RIBEIRO, P.A.; TORRANO RIBEIRO, C.

1999 Escavações arqueológicas no sítio RS. -TQ-58, Montenegro, RS, Brasil. Documentos. Fund. Univ. Fed. Rio Gd, 10(10):1-86.

MENTZ RIBEIRO, P.A.; CALIPPO, F.R.

2000 Arqueologia e História Pré-Colonial. In: Tagliani, P.R.; Mentz Ribeiro, P.A.;
Torres, L.H.; Alves, F.N. (Orgs.) Arqueologia, História e Sócio-Economia da restinga da Lagoa dos Patos: uma contribuição para o conhecimento e manejo da Reserva da Biosfera. Rio Grande, Editora da FURG: 13-40.

MUCKELROY, K.

1978 Maritime Archaeology. (New Studies in Archaeology).Cambridge: Cambridge University Press.

OKUMURA, M.M.M.; BOYADJIAN, C.H.C.; EGGERS, S.

2005/ Análise de exostose do meato auditivo

2006 externo como um marcador de atividade aquática em restos esqueletais humanos da costa e do interior do Brasil. Revista do Musen de Arqueologia, 15/16: 181-189.

PEIXOTO, M.V.

1989 Avaliação radiológica do torus auditivus nos grupos formadores de Sambaquis do litoral meridional brasileiro: contribuição ao estudo dos traços não métricos em populações pré-históricas do Brasil. Dissertação de Mestrado. Rio de Janeiro, Depto. de Anatomia Humana.

RAMBELLI, G.

2003 Arqueologia subaquática do Baixo Vale do Ribeira, SP. Tese de Doutorado em Arqueologia. São Paulo, Museu de Arqueologia e Etnologia, Faculdade de Filosofia, Letras e Ciências Humanas, Universidade de São Paulo.

READ, J.

1996 The Indian Ocean in Antiquity. London: Kegan Paul International in association with the British Museum.

SCHELL-YBERT, R.; EGGERS, S.; WESOLOWSKI, V.; PETRONILHO, C.C.; BOYADJIAN, C.H.; DE BLASIS, P.A.D.; BARBOSA-GUIMARÃES, M.; GASPAR, M.D.

2003 Novas perspectives na reconstituição do modo de vida dos sambaquieiros: uma abordagem multidisciplinar. Revista de Arqueologia, Sociedade de Arqueologia Brasileira, 16: 109-137.

SEMENOV, S.A.

1970 Prehistoric Technology: an Experimental Study of the oldest Tools and Artifacts from traces of Manufacture and Wear. Great Britain: Adams \& Dart.

STEWART, H.

1977 Indian Fishing. Early Methods on the North

[1982] west Coast. Vancouver. Toronto: Douglas $\&$ McIntyre. 
TENÓRIO, M.C.

1999 Os fabricantes de machado da Ilha Grande. In: Tenório, M.C. (Org.) Préhistória da Terra Brasilis. Rio de Janeiro: EDUFRJ: 233-246.
WHITING, W.C.; ZERNICKE, R.F.

2001 Biomecânica da Lesão Musculoesquelética. Rio de Janeiro: Guanabara Koogan.

Recebido para publicação em 17 de outubro de 2011. 